\title{
Thalamic abscess in a patient with hereditary hemorrhagic telangiectasia successfully treated with an empiric antibiotic regime: case report and review of the literature
}

\author{
Xavier A. Santander ${ }^{1 *}$ (D) Anwar Saab ${ }^{1}$, Juan Manuel Revuelta-Barbero² and Elena Múñez ${ }^{3}$
}

\begin{abstract}
Background: Hereditary hemorrhagic telangiectasia (HHT) is a rare autosomal dominant disease associated with neurological complications, including cerebral abscesses (CA). They tend to be unique, supratentorial and lobar. While the surgical intervention is a rule of thumb when treating and diagnosing the etiology of these lesions, this is not always possible due to dangerous or inaccessible locations. We report the case of a patient solely treated with empiric antibiotics without stereotaxic intervention and satisfactory results.

Case presentation: We present the case of a 21-year-old patient with a right thalamic abscess due to HHT and pulmonary arteriovenous malformations, previously embolized, treated solely with antibiotics. At first, we contemplated the possibility of a stereotaxic biopsy, but the high-risk location and the fact that our patient received a previous full course of antibiotic treatment (in another center), made us discard this intervention because of the low diagnostic yield. We started an empiric antibiotic regime. We followed up very closely the clinical and radiological evaluation the next weeks, adjusting our antibiotic treatment when necessary. The results were favorable from both the radiological and clinical aspects and 6 months after the diagnosis the images show its almost complete disappearance.
\end{abstract}

Conclusion: Carefully tailored antibiotic-only regime and vigilance of its adverse effects and close radiological following is a good treatment approach when surgery is not an option.

Keywords: Thalamic, Abscess, Telangiectasia, Antibiotics, Case-report

\footnotetext{
* Correspondence: xavier.santander@gmail.com

'Department of Neurosurgery, University Hospital Puerta de Hierro Majadahonda, Madrid, Spain

Full list of author information is available at the end of the article
}

(c) The Author(s). 2021 Open Access This article is licensed under a Creative Commons Attribution 4.0 International License, which permits use, sharing, adaptation, distribution and reproduction in any medium or format, as long as you give appropriate credit to the original author(s) and the source, provide a link to the Creative Commons licence, and indicate if changes were made. The images or other third party material in this article are included in the article's Creative Commons licence, unless indicated otherwise in a credit line to the material. If material is not included in the article's Creative Commons licence and your intended use is not permitted by statutory regulation or exceeds the permitted use, you will need to obtain permission directly from the copyright holder. To view a copy of this licence, visit http://creativecommons.org/licenses/by/4.0/ The Creative Commons Public Domain Dedication waiver (http://creativecommons.org/publicdomain/zero/1.0/) applies to the data made available in this article, unless otherwise stated in a credit line to the data. 


\section{Background}

Osler-Weber-Rendu syndrome or hereditary hemorrhagic telangiectasia (HHT) is a rare entity consisting of angiomata of the skin, mucous membranes and viscera. It is an autosomal dominant disorder with high penetrance $[1,2]$. From the genetic point of view, HHT is a heterogeneous disorder. At least three genes have been identified as culprits: Endoglin, activin A receptor type II-like 1 and SMA-and MAD related protein 4 [3]. Common features are diverse types of bleeding originated from the angiomas, including epistaxis, hemoptysis, hematuria and melaena. The diagnosis is based on the Curacao criteria [4].

Mortality and morbidity are related to central nervous system (CNS) complications, like cerebral abscess (CA), ischemic stroke, transient cerebral ischemic attack, and cerebral hemorrhage due to arterio-venous malformations. In the presence of pulmonary arterio-venous malformations (P-AVM) there is a well-stablished relationship with $\mathrm{CA}$ [5].

When a CA is diagnosed, there is an accepted course of action: surgery, diagnosis and antibiotic treatment. Literature reporting cases solely treated with antibiotics without surgery are scarce in the literature and our case is a great example of how to get satisfactory results tailoring a personalized empiric antibiotic treatment when surgery is not doable.

\section{Case presentation}

A 21-year-old man, with a previous diagnosis of HHT and embolization of multiple P-AVM in the past, was admitted at another hospital, while on holidays, with fever, headache and malaise. A non-enhanced computed tomography (CT) of the head showed no significant findings. He was diagnosed with typhoid fever based on clinical features and serology. Consequently, he was discharged with oral antibiotic therapy consisting of ciprofloxacin $500 \mathrm{mg}$ bid and cotrimoxazole 800/160 mg bid.
Two weeks later, he came to our emergency department because of the persistent fever and headache. At our center, the neurologic, cardiac and pulmonary examination were normal. Routine hematology showed a white cell count of $17.6 \times 10^{3} / \mathrm{ml}$ leucocytes (4.0-11.5) and $14.33 \times 10^{3} / \mathrm{ml}$ neutrophils $(1.5-7.5)$. The C-reactive protein was $2.00 \mathrm{mg} / \mathrm{L}(0.1-10)$ and the arterial blood gases were normal. A chest radiograph appeared to be normal other than visualization of previous embolization material (Fig. 1).

A contrast-enhanced CT scanner of the head revealed a mass in the right thalamic-capsular region, compatible with an abscess. An MRI, performed later, confirmed the findings (Fig. 2) showing the typical ring-like contrast enhancement.

Further investigations were performed. A cardiac transesophageal echography was normal. A CT of his lungs confirmed the presence of embolization material inside the lumen of pulmonary vessels feeding the malformations. After reviewing the images with our radiology team, they concluded that the lesions were successfully treated. Pulmonary angiography was not performed in light of these results and because our patient was being followed for that pathology in another center.

\section{Treatment}

After carefully evaluating the images and discussing treatment options with our patient, we decided to start with intravenous empiric medical treatment, due to the high risk of a surgical intervention. However, we contemplated the possibility of a stereotaxic biopsy, but considering our patient received a previous full course of antibiotic treatment we discarded this intervention because of the low diagnostic yield. Thus, treatment was started with intravenous linezolid $600 \mathrm{mg}$ tid, plus ceftazidime $2 \mathrm{~g}$ tid and metronidazole $500 \mathrm{mg}$ qid. A course

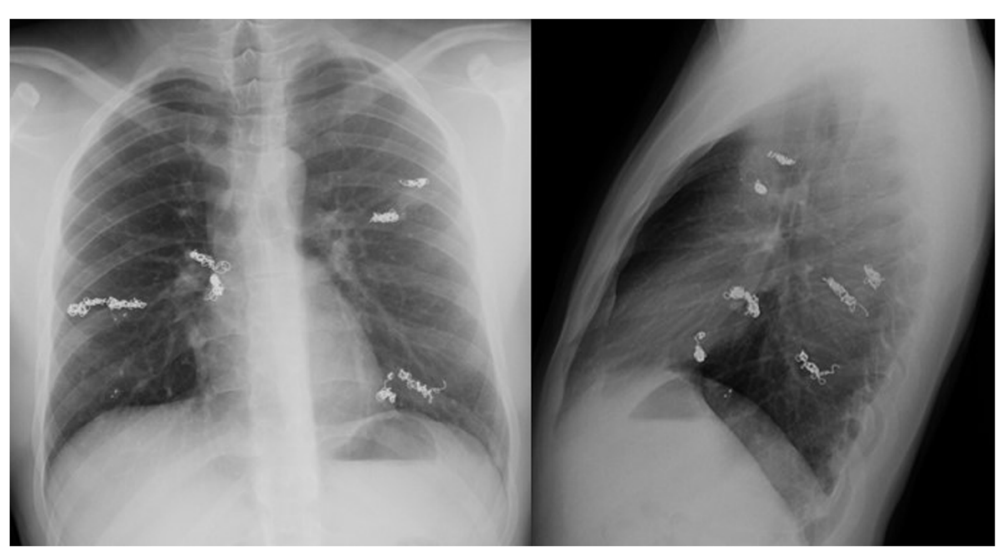

Fig. 1 Chest X-radiograph showing previous material embolization but no signs of infection coming from the lower air pathway 


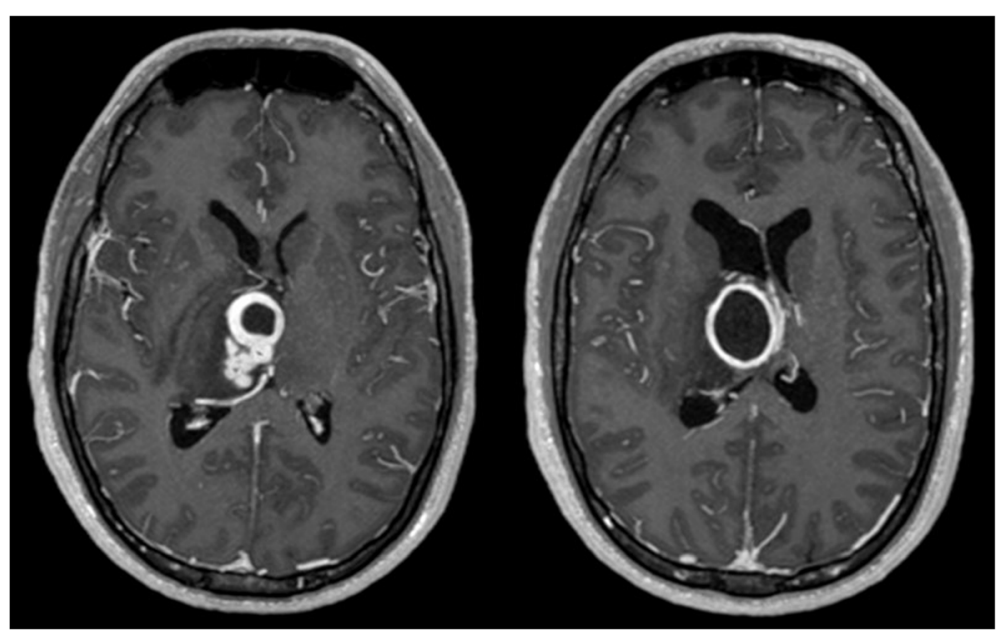

Fig. 2 Initial T1W1 C+ MRI at the time of diagnosis. The presence of a typical ring-like enhancing region suggesting a polylobulated abscess is shown. The lesion was in the right capsular-thalamic region, deforming the lateral ventricular architecture and deviating the midline. T1W1 C+ (T1 weighted image with gadolinium enhancement)

of corticosteroids, dexamethasone $4 \mathrm{mg}$ tid, was also initiated.

After 2 weeks, a new CT evidenced a favorable radiological evolution with reduction of the lesion. He was afebrile, the headache had disappeared, and his general condition had dramatically improved. We switched linezolid and metronidazole to an oral regimen. After 1 week he remained asymptomatic and we decided to rotate the antibiotic regimen to ceftriaxone $2 \mathrm{~g}$ bid and ciprofloxacin $750 \mathrm{mg}$ bid, maintaining the linezolid and metronidazole, due to its better tolerance profile and towards to a possible discharge. By that time, he was almost finishing his waning course of corticosteroids. We performed a new MRI control showing good radiological results (Fig. 3a).

Three days after, he presented headache of moderate intensity and fever. A new CT scan showed an increase in size of the thalamic abscess that we confirmed with a new MRI (Fig. 3b). We attributed this evolution to the change of antibiotics. Our patient remained neurological stable and that's why we decided to reintroduce ceftazidime $2 \mathrm{~g}$ tid and re-started a new course of corticosteroids, discarding a surgical intervention. He started to improve again. A new MRI performed 10 days after this regimen demonstrated a reduction in the size of the lesion (Fig. 3c).

In the day 21 (Table 1), after a hematologic control showed an increase in hepatic enzymes: AST: $192 \mathrm{U} / \mathrm{L}$ (6.0-40) ALT: 649 U/L (6.0-40), GGT: 666 U/L (8.061), gastrointestinal discomfort and hyporexia, we performed an abdominal echography and found signs of hepatopathy. Then again, due to the toxicity of ceftazidime and metronidazole, we changed to a new regimen consisting of linezolid and meropenem $1 \mathrm{~g}$ tid. Another MRI showed further shrinking of the lesion (Fig. 3D).
He remained stable with no neurologic deficit and a clear improvement of his hepatic profile. Because of the prolonged therapy with linezolid, he presented leucopenia: $2.8 \times 10^{3} / \mathrm{ml}$ leucocytes (4.0-11.5). After a final antibiotic rotation to cotrimoxazole and moxifloxacin orally, he was discharged with radiological stability, clinical improvement and corrected hematologic disturbances.

\section{Discussion and conclusion}

Almost $50 \%$ of patients with P-AVM have a family history of HHT, and $10 \%$ of members of HHT families have a P-AVM [6]. As estimated by Roman [7] the frequency of a brain abscess in a patient with HHT and a P-AVM is $5 \%$, this is $\times 10^{3}$ times the risk of developing CNS infection in the general population [6]. Although the pathogenesis is not well understood, it is believed to be the result from right-to-left pulmonary shunts and paradoxical embolization. Two main mechanisms have been proposed: 1) septic micro emboli that can reach the CNS, from the digestive tube, favored by polycythemia and hypoxic conditions that decrease resistance of cerebral tissue to bacteria invasion and 2) secondary infection of previous brain microinfarctions during transient bacteremia [8-11].

As a rule of thumb, the first diagnosis to be considered in a patient with positive history of P-AVM and HHT and a cerebral mass should be a CA. This was the case of our patient. On the other hand, one should think about P-AVM when a patient has a cerebral abscess and no previous history suggesting any infectious origin [12, 13]. Actually, many patients with P-AVM are asymptomatic before presentation with neurologic complications such as brain abscess or stroke [14]. 

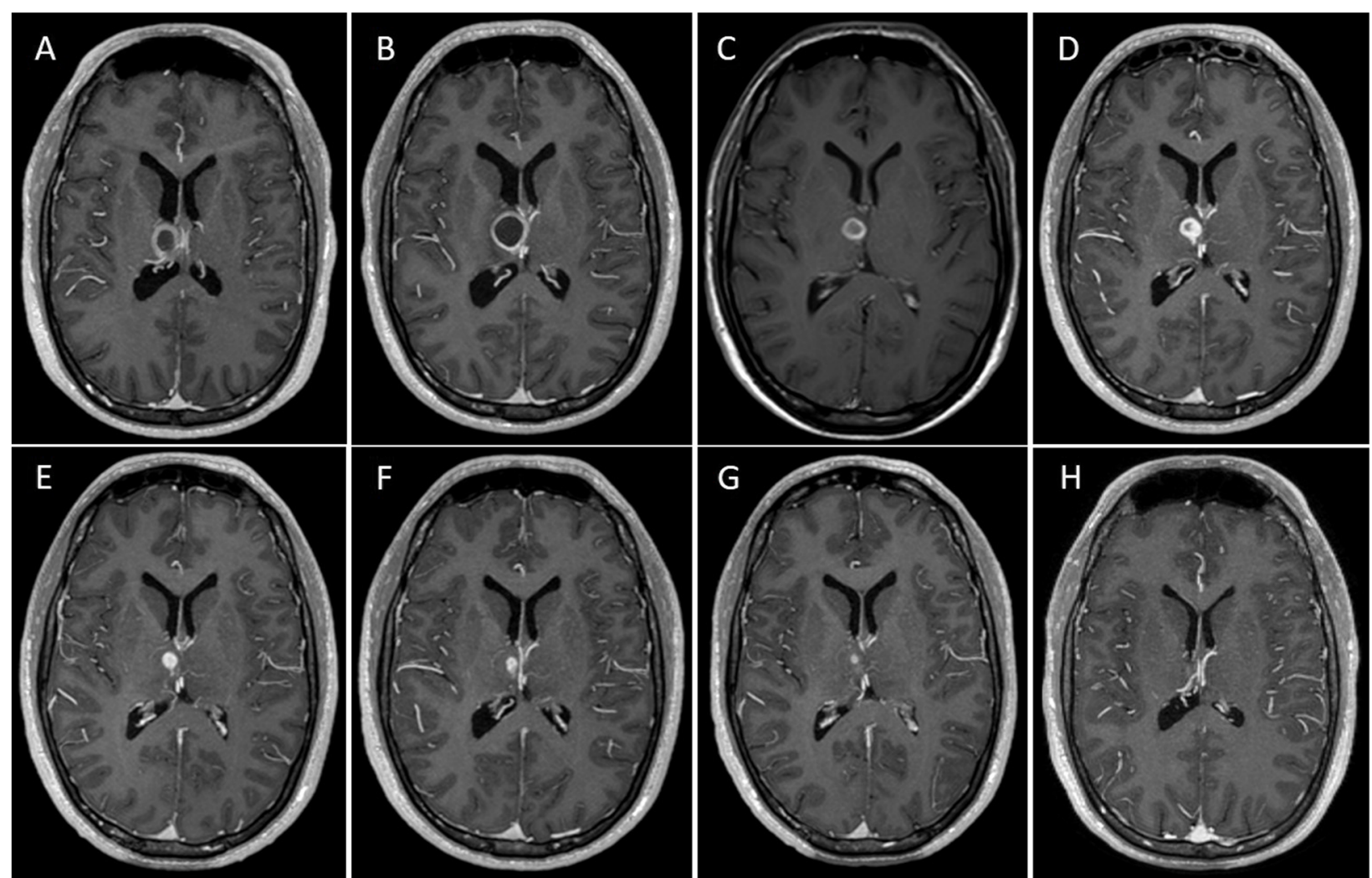

Fig. 3 Multiple T1WI C+ sequences showing the radiological evolution of our case. a This first image shows the improvement after the first course of antibiotics and corticosteroids. $\mathbf{b}$ The radiological and clinical worsening, shortly after the waning of corticosteroids and the change of antibiotics. c Sequence obtained 10 days after the last image, showing good evolution after the reintroduction of ceftriaxone. From here on our patient had a maintained good evolution during following months, after we refined the empirical antibiotic treatment. $\mathbf{d}$ Last image showing steadiness in the size of the lesion, previous to discharge with good clinical stability. e-f-g Images taken at 3, 4 and 5 months after discharge. $\mathbf{h}$ The last and actual image showing no further presence of the lesion. T1W1 C+ (T1 weighted image with gadolinium enhancement)

These CAs, when secondary to HHT, are generally supratentorial (frontal lobe in $40 \%$ of cases), lobar and unique [9, 15]. Our patient had multiple satellite lesions around a main one in the thalamic region (deep basal ganglia). This presentation is rare and estimated around $4 \%$ of all CAs [15].

The gold standard for P-AVM is the digital subtraction angiography. It allows diagnosing and treating by embolizing the main vessel feeding the malformation.
However, appropriate management does not necessarily exclude the possibility of CA recurrence. In the series by Mathis et al., $15.4 \%$ of patients had recurrence even when they were adequately treated [15]. The recurrence in other locations, different from the first presentation, reveals the crucial role of P-AVM. Failure of treatment after a successful embolization of the fistula is considered low by 5 years as reported by White et al. [16].

Table 1 Hepatic profile and antibiotic regime during the treatment

\begin{tabular}{|c|c|c|c|c|c|c|c|c|c|c|c|c|c|c|c|}
\hline \multirow{3}{*}{$\begin{array}{l}\text { Hepatic } \\
\text { enzyme (U/ } \\
\text { L) } \\
\text { AST }\end{array}$} & \multicolumn{15}{|c|}{ ANTIBIOTIC REGIME } \\
\hline & \multicolumn{4}{|c|}{$\begin{array}{l}\text { LINEZOLID } \\
\text { METRONIDAZOLE CEFT } \\
\text { AZIDIME }\end{array}$} & \multicolumn{2}{|c|}{$\begin{array}{l}\text { CEFTRIAXONE } \\
\text { CIPROFLOXACINE LINEZOLID } \\
\text { METRONIDAZOLE }\end{array}$} & \multicolumn{3}{|c|}{$\begin{array}{l}\text { LINEZOLID } \\
\text { METRONIDAZOLE CEFT } \\
\text { AZIDIME }\end{array}$} & \multicolumn{3}{|c|}{$\begin{array}{l}\text { LINEZOLID } \\
\text { MEROPENEM }\end{array}$} & \multicolumn{3}{|c|}{$\begin{array}{l}\text { COTRIMOXAZOLE } \\
\text { MOXIFLOXACIN }\end{array}$} \\
\hline & 14 & 15 & 21 & 35 & 24 & 36 & 85 & 130 & 192 & 161 & 159 & 97 & 61 & 35 & 21 \\
\hline ALT & 22 & 28 & 24 & 30 & 42 & 43 & 189 & 270 & 649 & 473 & 314 & 397 & 224 & 113 & 41 \\
\hline GGT & 22 & 26 & 27 & 33 & 42 & 51 & 150 & 225 & 666 & 610 & 568 & 358 & 64 & 38 & 22 \\
\hline \multirow[t]{2}{*}{ Therapy Day } & 1 & 5 & 10 & 14 & 20 & 27 & 33 & 40 & $48^{*}$ & 51 & 55 & 60 & $1 \mathrm{~m}$ & $2 m$ & $3 m$ \\
\hline & \multicolumn{6}{|c|}{ INPATIENT } & & & & & & & \multicolumn{3}{|c|}{ OUTPATIENT } \\
\hline
\end{tabular}


The treatment of every CA should be multidisciplinary. It must encompass a medical and surgical approach. General recommendations are: 1 ) surgical drainage if lesion $>2.5 \mathrm{~cm}$ in diameter; 2) CT or MRI imaging every 15-20 days and 3) 6-8 weeks of intravenous antibiotic treatment [9]. The concept of treating only with antibiotics when the lesion is not amenable to surgery is not wild; however, literature describing this type of approach is scarce. This is why we believe this case can highlight the importance of taking into account this kind of approach. Non-operative treatment of $\mathrm{CA}$ has been successfully reported in some cases but this option should be reserved for poor surgical candidates or small lesions in inaccessible areas $[9,17]$. In the series reviewed by Sell et al. [9], one patient had no biopsy and survived only with medical treatment. Nonetheless, stereotactic drainage is usually considered the treatment of choice [18]. In our case our patient had a thalamic CA, from our point of view, not amenable to surgery and he received previously a course of antibiotics at another center. We considered a surgical intervention not recommended because of the high risks and low yield ratio of diagnosis after antibiotics treatment. Thus, we decided to manage this CA only with antibiotics.

We agree there is a limitation when using antibiotics if no bacterial agent is previously identified, but the vast majority of microorganisms found in $\mathrm{CA}$ related to HHT involves anaerobic or facultative anaerobic bacteria. Streptococcus is the most common organism [6]. Staphylococcal infection, although a common organism in extra-cerebral infections in this group, is somewhat extraordinary in the CNS, being more common (up to $30 \%$ and always associated with endocarditis) in patients with CA and no HHT. Moreover, CA related to HHT tend to be of multiple germs ( $2-3$ bacteria) which is a striking difference when compared to non-HHT related CA [15]. This highlights the utmost importance of carefully selecting and tailoring the empiric antibiotic therapy, when there is no option to obtain samples for cultures. Mortality, historically considered high in the pre-antibiotic era, has considerably improved in part due to the advancements in imaging modalities, less invasive surgical techniques and a broader antibiotic spectrum and efficacy.

As of 6 months after the initial diagnosis, our patient is asymptomatic and his lesion has almost completely disappeared as demonstrated in the radiological followup (Fig. 3 e, f, $g$ and h).

Proper knowledge of the relationship between CA and HHT is vital to raise the level of suspicion, especially in patients with no underlying cause. Previous detection and embolization of P-AVM reduces the recurrence of CA but does not exclude them completely, as was the case of our patient.
Finally, our case highlights that carefully selecting the antibiotic regime, vigilance of adverse effects and close radiological following is of utmost importance when surgery is not an option.

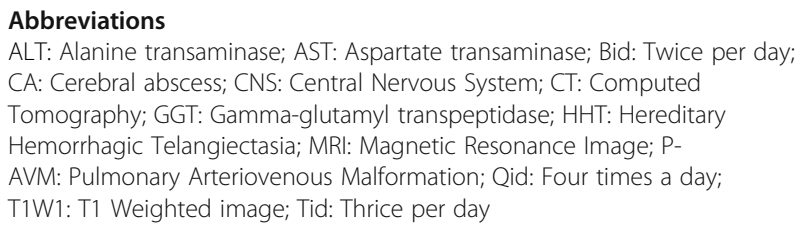

\section{Acknowledgements}

Not applicable.

\section{Authors' contributions}

XS performed the clinical history, wrote the manuscript, selected the images, and revised the literature. AS was the neurosurgeon in charge of the patient and contributed to the writing, reviewing of the manuscript, and selecting the images and literature as well. He was also involved in the follow-up of our patient. JMR contributed to the review of the manuscript. EM was the infectious disease specialist in charge of the patient, who tailored the treatment accordingly and contributed to the writing of the manuscript. All authors read and approved the final manuscript.

\section{Funding}

The authors declare they had no funding for this work.

Availability of data and materials

Our manuscript is a case-report. The available-data section is not applicable.

\section{Declarations}

Ethics approval and consent to participate

Not applicable.

\section{Consent for publication}

We have obtained the proper written consent from our patient for his personal or clinical details along with any identifying images to be published in this study.

\section{Competing interests}

The authors declare that they have no competing interests.

\section{Author details}

${ }^{1}$ Department of Neurosurgery, University Hospital Puerta de Hierro Majadahonda, Madrid, Spain. ${ }^{2}$ Department of Neurosurgery, University Hospital Clínico San Carlos, Madrid, Spain. ${ }^{3}$ Department of Infectious Diseases, University Hospital Puerta de Hierro Majadahonda, Madrid, Spain.

Received: 5 August 2020 Accepted: 3 March 2021

Published online: 19 March 2021

\section{References}

1. Bird RM, Hammarsten JF, Marshall RA, Robinson RR, Beckner E, et al. Family Reunion: study of hereditary hemorrhagic telangiectasia. Engl J Med. 1957; 257(3):105-9. https://doi.org/10.1056/NEJM195707182570303.

2. El-Houcheimi I, Hardwidge C, Walter P, Jalaluddin M. Brain abscess and hereditary haemorrhagic telangiectasia: a report of three cases. $\mathrm{Br} J$ Neurosurg. 1998;12(1):15-7. https://doi.org/10.1080/02688699845447.

3. Tørring PM, Lauridsen MF, I Dali C, et al. Familial cerebral abscesses caused by hereditary hemorrhagic telangiectasia. Clin Case Rep. 2017;5(6):805-8. Published 2017 Apr 13. https://doi.org/10.1002/ccr3.785.

4. Faughnan ME, Palda VA, García-Tsao G, et al. International guidelines for the diagnosis and management of hereditary hemorrhagic telangiectasia. J Med Genet. 2011;48(2):73-87. https://doi.org/10.1136/jmg.2009.069013.

5. Cottin V, Chinet T, Lavole A, et al. Pulmonary arteriovenous malformations in hereditary hemorrhagic telangiectasia: a series of 126 patients. Medicine (Baltimore). 2007;86(1):1-17. https://doi.org/10.1097/MD.0b013e31802f8da1. 
6. Dupuis-Girod S, Giraud S, Decullier E, Lesca G, Cottin V, Faure F, et al. Hereditary hemorrhagic telangiectasia (Rendu-Osler disease) and infectious diseases: an underestimated association. Clin Infect Dis. 2007;44(6):841-5. https://doi.org/10.1086/511645.

7. Roman G, Fisher M, Perl DP, Poser CM. Neurologic manifestations of hereditary hemorrhagic telangiectasia (Rendu-Osler-weber disease): report of 2 cases and review of the literature. Ann Neurol. 1978;4(2):130-44. https://doi.org/10.1002/ana.410040207.

8. Fumiyiki M, Susumu O, Takashiro O, Atsutumi M, Hiroshi O, Hiromasa H. Brain abscess associated with congenital pulmonary arteriovenous fistula. Surg Neurol. 1990;34:439-41.

9. Sell B, Evans J, Horn D. Brain abscess and hereditary hemorrhagic telangiectasia. South Med J. 2008;101(6):618-25. https://doi.org/10.1097/SMJ. 0b013e318172f716.

10. Sisel RJ, Parker BM, Bahi OP. Cerebral symptoms in pulmonary arteriovenous fistula A result of paradoxical emboli. Circulation. 1970;41(1):123-8. https:// doi.org/10.1161/01.cir.41.1.123.

11. Walter AH. Hereditary hemorrhagic telangiectasia (Rendu-Osler- weber disease) presenting with polymicrobial brain abscess. J Neurosurg. 1994;81: 294-6.

12. Fuentes Pradera M, Otero Candelera R, Ortega Ruiz F, Franco E (1999) Absceso cerebral como primera manifestación de una fístula arteriovenosa pulmonar familiar. Arch Bronconeumol; 35:407-409 (Article in Spanish).

13. Gelfand MS, Stephens DS, El H, Allord RH, Kaiser AB. Brain abscess: association with pulmonary arteriovenous fistula and hereditary hemorrhagic telangiectasia: report of three cases. Am J Med. 1988;85(5): 718-20. https://doi.org/10.1016/50002-9343(88)80249-3.

14. Wallace $\mathrm{GM}$, Shovlin CL. A hereditary haemorrhagic telangiectasia family with pulmonary involvement is unlinked to the known HHT genes, endoglin and ALK-1. Thorax. 2000;55(8):685-90. https://doi.org/10.1136/thora X.55.8.685.

15. Mathisa S, Dupuis-Girodb S, Plauchub H, et al. Cerebral abscesses in hereditary haemorrhagic telangiectasia: a clinical and microbiological evaluation. Clin Neurol Neurosurg. 2012;114(3):235-40. https://doi.org/10.101 6/j.clineuro.2011.10.036

16. White RI, Lynch-Nyhan A, Terry P, Buescher P, Farmiett EJ, Charnas L. Pulmonary arteriovenous malformations: techniques and long-term outcome of embolotherapy. Radiology. 1988;169(3):663-9. https://doi.org/1 0.1148/radiology.169.3.3186989.

17. Mathisen GE, Johnson JP. Brain abscess. Clin Infect Dis. 1997;25(4):763-79. https://doi.org/10.1086/515541.

18. Tseng JH, Tseng MY. Brain abscess in 142 patients: factors influencing outcome and mortality. Surg Neurol. 2006;65(6):557-62. https://doi.org/10.1 016/j.surneu.2005.09.029.

\section{Publisher's Note}

Springer Nature remains neutral with regard to jurisdictional claims in published maps and institutional affiliations.

Ready to submit your research? Choose BMC and benefit from:

- fast, convenient online submission

- thorough peer review by experienced researchers in your field

- rapid publication on acceptance

- support for research data, including large and complex data types

- gold Open Access which fosters wider collaboration and increased citations

- maximum visibility for your research: over $100 \mathrm{M}$ website views per year

At BMC, research is always in progress.

Learn more biomedcentral.com/submissions 